\title{
COMPETENCES OF PRODUCTION MANAGERS IN THE BIOMATERIAL SECTOR: STUDY IN A HIGH MEDICAL TECHNOLOGY MULTINATIONAL COMPANY
}

\author{
COMPETÊNCIAS DOS GESTORES DE PRODUCÃO DO SETOR DE BIOMATERIAIS: \\ ESTUDO EM MULTINACIONAL DE ALTA TECNOLOGIA MÉDICA
}

\section{COMPETENCIAS DE LOS GESTORES DE PRODUCCIÓN DEL SECTOR BIOMATERIALES: ESTUDIO EN UNA EMPRESA MÉDICA MULTINACIONAL DE ALTA TECNOLOGÍA}

\section{(D)Camila Valadares Salomão ${ }^{1}$ \\ Reginaldo de Jesus Carvalho Lima ${ }^{2}$ \\ Domingos Antônio Giroletti ${ }^{3}$ \\ iD Adelaide Maria Coelho Baêta ${ }^{4}$}

\section{Cite as - American Psychological Association (APA)}

Salomão, C. V., Lima, R. J. C., Giroletti, D. A., \& Baêta, A. M. C. (2021, May/Aug.). Competences of production managers in the biomaterial sector: study in a high medical technology multinational company. International Journal of Innovation - IJI, São Paulo, 9(2), 267-294. https://doi.org/10.5585/iji.v9i2.18777.

\begin{abstract}
Objective: This article aims to discuss the configuration of the competence approach in a multinational company that manufactures high-tech medical devices. It analyzes the managerial competences related to the production managers.

Method: A descriptive Case Study of the company was carried out. As for data collection, it involved a semi-structured interview and document analysis. The data obtained were submitted to Content Analysis with determination of thematic categories.

Originality/Relevance: The study carried out is justified by the possibility of contributing to the debate, illuminating aspects inherent to the Production area, in an innovative sector.

Results: The research revealed an oxymoron. Although Valvmed is a multinational company that manufactures high-tech medical devices and operates in a dynamic sector, the competence approach is still configured in a traditional way. Although the area is characterized by its mechanistic and technical nature, it was possible to identify the demand for relational and behavioral competences that point out the relevance of the social content of the work.

Social / management contributions: The research contributes to the managers who work in this field, insofar as it stimulates reflections about the complexity inherent to production management and the need for the company to make efforts to improve management competences that enhance human interaction. Theoretical/methodological contributions: Regarding the competence approach, the need to deepen the understanding of the dynamics adopted in the Production area in a high-tech medical company should be considered.

\footnotetext{
1 Mestre em Administração. Faculdade Pedro Leopoldo - FPL. Pedro Leopoldo - Minas Gerais - Brasil. camilavaladaress@yahoo.com.br

2 Doutor em Administração. Faculdade Pedro Leopoldo - FPL. Pedro Leopoldo - Minas Gerais - Brasil. regilima.jesus@gmail.com

3 Doutor em Antropologia Social. Faculdade Pedro Leopoldo - FPL. Minas Gerais - Brasil. domingosgiroletti@ gmail.com

4 Doutora em Engenharia de Produção. Universidade Federal de Minas Gerais - UFMG. Belo Horizonte - Minas Gerais - Brasil. acoelhobaeta@ gmail.com
} 
Keywords: Managerial competencies. Production management. Multinational. Innovation. Biomaterials.

\section{Resumo}

Objetivo: Este artigo tem como objetivo discutir a configuração da abordagem de competências em uma empresa multinacional que fabrica dispositivos médicos de alta tecnologia. Considera as competências gerenciais relacionadas aos gestores de produção, na perspectiva dos próprios profissionais.

Método: Foi realizado um Estudo de Caso descritivo. A coleta de dados envolveu entrevista semiestruturada e análise documental. Os dados obtidos foram submetidos à Análise de Conteúdo com determinação de categorias temáticas.

Originalidade / Relevância: O estudo contribui para o debate sobre o tema, iluminando aspectos inerentes à área da Produção, em empresa multinacional que atua em setor inovador.

Resultados: A pesquisa revelou um oxímoro. Embora a Valvmed seja uma empresa multinacional que fabrica dispositivos médicos de alta tecnologia, na percepção dos gestores da área de Produção, a abordagem da competência ainda se configura de forma tradicional. Embora a área seja caracterizada pelo seu caráter mecanicista e técnico, foi possível identificar a demanda por competências relacionais e comportamentais que apontam a relevância do conteúdo social do trabalho.

Contribuições sociais / gerenciais: A pesquisa contribui para o conhecimento gerencial, na medida em que estimula reflexões inerentes à gestão da produção e à necessidade de a empresa aprimorar as competências gerenciais que potencializem a interação humana.

Contribuições teórico-metodológicas: Em relação à abordagem da competência, deve-se considerar a necessidade de aprofundar o entedimento acerca da dinâmica adotada na área de Produção, em uma empresa de alta tecnologia médica.

Palavras-chave: Competências gerenciais. Gerenciamento de Produção. Multinacional. Inovação. Biomateriais.

\section{Resumen}

Objetivo: Este artículo tiene como objetivo discutir la configuración del enfoque por competencias en una multinacional que fabrica dispositivos médicos de alta tecnología. Considera las habilidades gerenciales de los gestores de producción, desde la perspectiva de los propios profesionales.

Método: Se realizó un Estudio de Caso descriptivo. La recolección de datos involucró entrevistas semiestructuradas y análisis de documentos. Los datos obtenidos fueron sometidos a Análisis de Contenido con la determinación de categorías temáticas.

Originalidad / Relevancia: El estudio contribuye al debate sobre el tema, destacando aspectos inherentes al área de Producción, en una multinacional de un sector innovador.

Resultados: La búsqueda reveló un oxímoron. Aunque la Valvmed sea una multinacional que fabrica dispositivos médicos de alta tecnología, en la percepción de los gestores del área de Producción, el enfoque por competencias aún se configura de manera tradicional. Aunque el área sea caracterizada como mecanicista y técnico, se pudo identificar la demanda de habilidades relacionales y conductuales que apuntan a la relevancia del contenido social del trabajo.

Contribuciones socio-gerenciales: La investigación contribuye al conocimiento gerencial, estimulando las reflexiones inherentes a la gestión de la producción y la necesidad de la empresa de mejorar las habilidades gerenciales que potencian la interacción humana.

Contribuciones teórico-metodológicos: Sobre el enfoque por competencias, se debe considerar la necesidad de profundizar la comprensión de las dinámicas adoptadas en el área de Producción en una empresa médica de alta tecnología.

Palabras clave: Competencias gerenciales. Gestión de la producción. Multinacional. Innovación. Biomateriales. 


\section{Introduction}

It is known that the search for innovation and competitiveness through the competency approach has stimulated important reflections on the generation of value in organizations. The subject has stimulated the production of a vast literature that manages to aggregate different theoretical and methodological perspectives (Lima, Barbosa \& Cintra, 2015; Barbosa, 2007, Fleury \& Fleury, 2001). The intensification of globalization and the application of new technologies have influenced, in a very significant way, the nature of work. Profound changes have affected the corporate world and altered the competitive dynamics in the most varied sectors.

The competency model considers the relevance of the convergence of efforts to achieve organizational objectives, where the need for alignment between strategies and actions is highlighted. The debate on competences places the human element as the central agent of this process and, with regard to performance at work, directs attention to the network of factors capable of affecting the worker's performance. Montezano, Medeiros, Isidro-Filho and Petry (2019) identified organizational and individual improvements arising from the adoption of management models based on the concept of competencies.

In the area of human health, given the frequent innovations and intense changes that have taken place, several organizations have moved towards new management models. In this referred sector, companies have a dynamic and innovative production base in order to offer goods and services in line with the high standards of quality and performance required. According to Pereira (2018, p.97), it is a context characterized by "complex systems, which demand increasing investments in training, research, development and innovation, in order to obtain successful innovation cases." This author considers that "innovation in the area of health includes a study of excellence, which requires investments in the infrastructure of Science, Technology and Innovation in Health CT \& I / S, articulated with the industrial base, thus promoting and qualifying its consolidation." Such articulation proves to be essential within the scope of the Industrial Economic Complex of Health, which consists of chemical and biotechnological-based industrial sectors (drugs, medicines, immunobiologicals, vaccines, blood products and reagents), and of mechanical, electronic and material basis (equipment mechanical, electronic, prosthetic, orthotic and material). (mechanical and electronic equipment, prostheses, orthoses and other materials).

Although the World Health Organization (WHO) pointed out the increase in cardiac pathologies in the beginning of the 21 st century, according to Oliveira et. al. (2010 cited by 
Pires, Bierhalz \& Moraes, 2015), in the last decades there has been a drop in the proportion of deaths as a result of these diseases due to the growing technological advance and rapid development in the health area, mainly due to the innovations that were introduced in surgical and drug treatments. It is important to highlight the relevant role played by the biomaterials sector in contemporary times. According to Pires, Bierhalz and Moraes (2015), biomaterials comprise a representative fraction of the products used in the health area, and whose application in the correction of the most diverse types of problems dates back to antiquity. From the point of view of these authors, biomaterials are defined as devices that come into contact with biological systems, and may consist of compounds of synthetic or natural origin, as well as chemically modified natural materials. Some of them, such as pig heart valves and human skin flaps, treated for use as implants, do not necessarily involve the manufacture of the raw material used.

And it is in this context of instabilities, and marked by consecutive innovations, that managerial competencies have become decisive for the achievement of organizational objectives, as well as for overcoming challenges. It is important to consider the transformations inherent to the Fourth Industrial Revolution, which is based on the expansion of interfaces between sciences and innovations in fields such as Robotics, Artificial Intelligence (AI), Big Data and Internet of Things (IoT). The so-called Industry 4.0 implies changes in the industrial model, while Society 5.0 implies changes in the social dynamics itself (Harari, 2018, Schwab, 2016).

The discussion about managerial competences has, for a long time, stimulated discussions at the theoretical level, and has generated debates in the corporate world. Managers play a central role in the operationalization of organizational strategies and act as interlocutors between the different levels of the company (Quinn, Faerman, Thompson \& McGrath, 2003). There is, therefore, a need for multiple competences. The model proposed by Paiva (2007) enables a comprehensive analysis of managerial competencies, based on the following categories: cognitive competence, functional competence, behavioral competence, values / ethics competence and political competence. This model is based on the works developed by Cheethan \& Chivers $(1996 ; 1998 ; 2000)$.

In biomaterials companies, the production manager acquires a relevant role in conducting activities related to the production process. According to what explains Slack, Chambers and Johnston (2009), when referring to the industrial field, the production manager exercises particular responsibility to manage some or all of the resources involved in the 
production function. Such a professional is essential as the management of operations is a constant challenge, since changes related to the market or environmental conditions, new technologies, new ideas, in the company's own paradigm, occur frequently and the production function will have to understand its consequences to respond to them (Pereira, Carvalho \& Santos, 2015, p.5).

Godoy and D'Amélio (2012, p.622) consider that the development of managerial competences should stimulate corporate social responsibility, proactivity and innovation in the organizational context. This is a complex process that, according to them, involves two integrated perspectives: organizational attribution and individual responsibility. In agreement with the point of view of authors such as Le Boterf (2003) and Zarifian (2001), Godoy and D'Amélio (2012) also recognize that the process of learning management competences goes beyond formal means, involving informal initiatives related to accumulated experience, knowledge and the needs of each individual. Authors such as Antonello (2011), Bitencourt (2005) and Leite (2011) share this idea. Cheetham and Chivers (1998) also recognize the complex and multifaceted nature of the construction of managerial competences, admitting that the manager makes use of general and specific competences according to the context of performance, with the level of personal development, as well as professional maturity.

What was shown above motivated the elaboration of this article, which adopts as its unit of analysis a multinational company that manufactures high-tech medical devices, called Valvmed. The implementation of strategic and operational guidelines, the obtainment and application of the various resources, and the observance of the strict quality parameters are activities that characterize the environment of this company. The market context is characterized by complexity, and the company must meet the requirements and standards established by legislation, as well as the specifications of international certification bodies. The production area plays an essential role and, in it, the determining role of the production manager is highlighted. This professional is especially important for achieving the goals established by the company. They are team leaders who work in the supervision and coordination of the process, in capturing, articulating and applying the various available resources.

The following central question was adopted as a starting point for the present study: in relation to managers working in Valmed's production area, how is the competence approach configured? In line with this question, several other questions guided the implementation of this study, which are as follows: What is the profile of the production manager at Valvmed? How do they define the concept of competence? What are the managerial competences required, 
according to the model of Paiva (2007)? What is the degree of importance of these competencies and the level of mastery over them, in the view of production managers? What alternatives have been used to develop these competences?

Regarding the competence approach, it should be considered that, for some time, several authors have pointed out the lack of standards and signaled the need to understand the different dynamics that govern the areas of an organization (Antonello, 2011, Barbosa, 2007, Bitencourt , 2005, Cheetham \& Chivers, 1998, Le Boterf, 2003, Leite, 2011, Quinn et al, 2003, Zarifian, 2001). Therefore, the study carried out is justified by the possibility of contributing to the debate, illuminating aspects inherent to the Production area, in an innovative sector. Studies with this focus have not been frequent in the literature. Bibliometric studies point to the need to expand production on this topic and to clarify certain aspects related to the competency approach. Silva et al (2017) carried out bibliometric research on electronic portals of Brazilian journals classified by Capes (Coordination for the Improvement of Higher Education Personnel), through the system called WebQualis, as being A1, A2, B1 and B2, in the Administration area. In the period from 2006 to 2016, they found that the production on the topic was considered modest, with 52 articles that pointed to a concentration in a reduced number of journals. Montezano et al (2019) also carried out a study on intellectual production, from 2008 to 2018, and noted that the main difficulties related to Competency Management models involve methodological and conceptual aspects. Although they have analyzed public administration, this finding is in line with the dynamics related to the private sector, as already indicated by Barbosa (2003, 2007). For Barbosa (2003), the "mosaic" of competence signals the need for studies that reveal specificities and adaptations related to the concept of competencies in organizations.

Regarding the structure of this article, it includes this introduction, the theoretical framework, the methodological procedures adopted in the research, the presentation and analysis of results, as well as the final considerations, in addition to the references.

\section{Theoretical framework}

This section presents the theoretical foundation of this research, discussing the competence and production management approach. 


\subsection{Competencies in organizations}

The competence approach is based on a vast literature that, according to what Barbosa (2007) explains, involves multiple points of view. Academic production on the topic involves discussions at different analytical levels.

At the collective level, the organizational competences that, according to Prahalad and Hamel (1990), should constitute the administrative process are of interest. In the view of these authors, the essential competencies, called core competences, must be valuable, rare, difficult to be imitated, and must favor the competitiveness of the business. Organizational competences express the company's differentials in the market and are supported by a complex network of efforts that involve the various levels of the structure. The process inherent to the development of organizational competences is complex and encompasses, in the view of Prahalad and Hamel (1990), a set of resources and competences capable of favoring the aggregation of value to the client. Fleury and Fleury (2001) highlight the close relationship between organizational competences and the strategy established by the management in function of the nature of the business and the variables that influence the competitive dynamics. Fleury and Fleury (2001) explain that the development of organizational competences involves the construction of learning systems capable of stimulating the aggregation of efforts in the different areas of the company.

As a result of the strategic approach, the theme motivated the search for alternatives capable of boosting business competitiveness and providing the alignment between human resources management policies and corporate guidelines (Ulrich, Allen, Brockbank, Younger \& Nyman, 2011). When emphasizing the role of the area responsible for people management, Dutra (2004) maintains the relevance of the articulation of the Human Resources subsystems, as well as the alignment of actions inherent to the activities of recruitment and selection, training and development, as well as the evaluation and the recognition of the value of employees.

Another perspective of discussion related to the theme involves the individual dimension. From this angle, the question of competence gains relevance, based on the work undertaken by the American psychologist David McClelland, who admitted the possibility of stimulating the development of the individual so that higher levels of performance can be obtained. Authors such as Boyatziz (1982) and Spencer and Spencer (1993) carry out studies based on the contributions of that author. From another perspective, the typical constructivist notion of the French school considers that several factors influence the competence of the individual. Le Boterf (2003) and Zarifian (2001) criticize the behaviorist approach for the fact 
that the concepts focus excessively on the individual and on the tasks prescribed for a given position.

The integration of elements related to the American and French currents can be seen in the Brazilian literature related to the theme. Fleury and Fleury (2001, p.21) define competence as "knowing how to act responsibly and recognized, which implies integrating, mobilizing, transferring knowledge, skills and resources, and which can add economic value to the organization and social value to the individual." Dutra (2004) relates individual competence to a person's capacity for commitment. Ruas (2010), as an example, defines competence as the ability to properly combine and mobilize the resources already developed. Carbone, Brandão, Leite and Vilhena (2011) understand it as a set of knowledge, skills and attitudes necessary to perform certain activities, but also the performance expressed by the person in a given context, in terms of behavior and achievements. Munck, Souza, Castro and Zagui (2011), in a concise form, clearly distinguish two aspects that involve individual competence: something that the individual needs to have for competent performance (judgment, sufficient knowledge, skill or strength - the so-called inputs); and the effective application of these capabilities to deal with any subject in its area of activity (the so-called outputs). Sant'Anna, Moraes and Kilimnik (2005), when studying the theme, highlight the relevance of social and relational aspects, as well as performance and commitment to organizational results.

Godoy, Antonello, Bido and Silva (2009) explain that the identification and assessment of competences are "controversial" issues and that involve several criticisms. In view of the diversity of understandings, Cheetham and Chivers $(1996 ; 1998 ; 2005)$ proposed a model of a holistic nature. Godoy et al (2009) explain that these authors adopted a theoretical-empirical approach that contemplated different reference models and extensive literature (Boyatzis, 1982, Jessup, 1991, Klemp, 1980, Mansfield \& Mathews, 1985, Schroder, 1989, Schön, 1983, 1987, as mentioned in Godoy et al., 2009, among others). The structure of the model by Cheetham and Chivers (2005) comprised the following components: cognitive competence, functional competence, behavioral competence and values / ethics competence. Beyond those mentioned above, they considered metacompetences, which represent generic competences and which can extend the others.

Paiva (2007), based on the works developed by Cheethan and Chivers (1996; 1998; 2000) points out restrictions inherent to traditional competence approaches. The author explains that they disregard the political and ideological dimensions that mark the intraorganizational and intraprofessional boundaries (Paiva, 2007, Paiva \& Melo, 2008). Paiva (2007), considering 
the influence of the work context and the environment for the activation of competences, suggested the inclusion of political competence in the original model proposed by Cheethan and Chivers (1998). The aforementioned author admits that power relations, inside and around organizations, affect behaviors and skills to be manifested with the use of other technical and intellectual competences. Therefore, he defines competence as follows:

Mobilization, in a particular way, by the professional, in his productive action, of a set of knowledge of a differentiated nature (from the intellectual, technical-functional, behavioral, ethical and political competences), in order to generate recognized results, individually (personal), collectively (professional) and socially (community) speaking. Then, professional competence is conceived as the meta-reunion, in a unique and productive way, of competences composed of varied knowledge (Paiva, 2007, p. 46).

It can be inferred that the model suggested by Paiva (2007) considers relevant and pertinent dimensions for the analysis of the studied company. Although there are different analytical models, such as those that supported the elaboration of the model by Cheethan and Chivers (1998), it is admitted that the dimensions considered by Paiva (2007) allow a comprehensive view about the different categories of competences, being particularly important for the study of the company in focus.

It is really necessary to highlight that the Human Resources Area (HRA) has traditionally been recognized as the area responsible for developing the professional competences required by companies, although it is not the only area involved in this process. The specialized literature shows that HRA takes on different configurations depending on the specifics of each organizational context. Organizations are at different stages and, consequently, adopt different HRA structures. Over time, the area has undergone some evolution in morphological and functional terms. In this way, the competency-based people management model emerged as a technology with a focus on aligning efforts in the organizational context. Within the scope of strategic perspective, it implies the identification of organizational competences and their unfolding into individual competences (Chouhan \& Srivastava, 2014, Avelino, Nunes \& Sarsur, 2016, Ceribeli, Maciel \& Guilarducci, 2017). Several authors, such as Barbosa (2007), explain that organizations have adopted differentiated initiatives and practices to develop the competences of their members. Practices vary depending on the industry, the business model, and the organizational culture itself (Barbosa, 2007; Lima, Barbosa, Baeta \& Giroletti, 2012).

Considering the object of study, the next section will discuss central aspects related to the area of Production Management in organizations. 


\subsection{Production management: necessary notes}

The production area plays a central role in organizations, and especially in those of an industrial nature. Fierce competition and the need to meet diverse demands have motivated the search for improvements related to production (Corrêa, Gianesi and Caon, 1997). Several initiatives that focus on increasing the efficiency levels and the operational income, have been carried out, such as: reduction of lead time, which is the time of resupply of an item purchased or manufactured, reduction of stocks and sizing of lots of production. It is admitted that, when using the available resources to the maximum, the economic gains are greater (Souza \& Pires, 1999). Regarding the external environment, the pressure exerted by customers who demand personalized and low-cost products must be taken into account. The production management contemplates the production planning, programming and control processes; and, likewise, production management systems, performance indicators and production monitoring and supervision. In this sense, it can be inferred that the metaphor of the machine, used by Morgan (1996), seems adequate for reading the context of production. In the sequence, aspects related to the various processes inherent to the area will be pointed out.

The first process involves the functions of planning, scheduling and production control. These functions are essential in the scope of production management, as highlighted by Corrêa, Gianesi and Caon (1997). Integration favors the proposition of significant improvements for the efficiency of production conditions, through the reduction of scheduling conflicts, of materials in process and reduction of flow time, increasing the use of production resources and adapting to irregular events of the necessary notes. This integration determines, to a certain extent, how much the company will serve its customers and gain a competitive position in the market. According to Corrêa, Gianesi and Caon (1997), the manufacturing environment is characterized by frequent changes related to the production mix, delivery times, and even the operation of equipment. It is essential that in this environment the production control is carried out in a timely manner, which in some cases can be in real time (Mahalik \& Moore, 1997), to react automatically to the various events that can occur on the plant floor.

The second process to be considered refers to the Production Management Systems (PMS). According to Corrêa, Gianesi and Caon (1997), these systems have the main objective of planning and controlling the manufacturing process, at all levels. According to these authors, the PMS, in order to fulfill their supporting role in achieving the company's strategic objectives, must be able to support and favor decision-making. These systems can determine what, when, how much and how to produce, regardless of the logic used by the company. The focus on 
rationalization has pushed the traditional material requirements planning systems (Material Requirements Planning - MRP) to their limits, and has also generated a demand for short-term control systems, among others. This can be achieved through the use of finite capacity programming systems, many of which do not need to work with the outputs of an MRP system. It is likely that later special control functions will be implemented, particularly on the shop floor, where the local level of control, integrated with the MPC sector will be common. With regard to the lead time, according to Kanet and Sridharan (1998), in the definition of these times, adjustments are made to cover various sources of uncertainties. Movement between operations may be uncertain, processing times may be uncertain, and queuing times may also be uncertain. The biggest contributors to lead times being inflated are the waiting times. These must be robust enough to anticipate all possible delays that a component may experience on the shop floor (Corrêa, Gianesi and Caon, 1997). The execution time of the same operation can vary randomly or according to some statistical recurrence and, thus, the lead times of the tasks represent average or expected values of the processing times (Souza \& Pires, 1999).

The third process consists of performance indicators. The Balanced Scorecard (BSC) is a performance measurement and management methodology developed in 1992 by Harvard Business School (HBS) professors Robert Kaplan and David Norton. The BSC decomposes the strategy in a logical way through objectives, indicators, targets and initiatives, in the four dimensions of business: finance, customers, internal processes and learning and growth.

And finally, the fourth process is the monitoring and supervision of production. According to Caetano, Meireles, Oliveira and Leão and Souza (1999), in manufacturing industries, monitoring systems are not widely used, and their applications are dedicated and specific to solve some problems. Caetano et. al. (1999) admits that monitoring mechanisms capable of providing information quickly and reliably can be a great differential to maintain the competitiveness of manufacturing companies.

In summary, it can be said that the new management challenges required not only the restructuring of organizational structures, but also the repositioning of managers in view of the changes in the profile and in the required managerial competences (Mintzberg, 2010, De Toni et al, 2012). The next section will present the methodological procedures adopted in the research 


\section{Methodology}

To achieve the established objectives, a qualitative research was carried out using the Case Study method. According to Yin (2010), this method enables the retention of holistic and significant aspects of real life.

The analysis unit was constituted by the Valvmed plant, located in the state of Minas Gerais, Brazil. The unit is part of a multinational corporation whose headquarters, founded in 1976, is located in the United States. Valvmed was the first bileaflet implantable mechanical heart valve manufacturer. The company has achieved global leadership in cardiac and neurological device technology through in-house development and strategic acquisitions. In Brazil, the company is dedicated to the manufacture of heart valves that are produced manually. The production process requires fresh biological material from pigs and cattle, obtained from qualified slaughterhouses and registered according to the recommended standards.

The research subjects consisted of all production managers who work at the supervisory level. In total, ten professionals who are responsible for managing the work teams, distributed in production cells, were surveyed. They have a strategic role on the front line and play a decisive role in conducting the activities performed by the operational core. The work they coordinate must comply with the strict quality criteria and certified by international organizations.

The collection of primary data involved individual and semi-structured interviews with production managers. Richardson $(1999$, p. 160) defines that the interview "is an important technique that allows the development of a close relationship between people. It is a form of communication in which certain information is transmitted". The script used included questions elaborated based on the theoretical framework and consisted of five blocks: (1) interviewee profile (2) concept of competence, (3) required competences, (4) degree of importance and level of competence mastery, (5) initiatives related to competence development.

All interviews were carried out during working hours, in the company's internal environment. The average duration of each one was fifty minutes. The interviews were recorded for later transcription with the research subjects' prior consent. The primary data were also obtained from internal documents made available by Valvmed, such as the job description and the company manual. Secondary data were obtained electronically on the institutional website, such as aspects related to the history and context of the company's operations.

The analytical procedure was based on the recommendations of Bardin (2011) and Silva and Fossá (2015). These authors explain that the conceptualization of Content Analysis can be 
conceived in different ways, considering the theoretical aspect and the intention of the researcher who develops it, whether adopting concepts related to the statistical semantics of discourse, or even aiming at inference by through the objective identification of message characteristics. They also emphasize the social character of Content Analysis, since it is a technique that aims to objectively produce inferences from a text to its social context.

The analysis was developed in three phases, which were: pre-analysis, exploration of the material and interpretation. In the first one, the general reading of the material obtained through interviews with Valvmed's production managers was carried out. In this phase, the systematization of the initial ideas extracted from the theoretical framework was carried out, and the analytical frameworks were also established, based on the model proposed by Paiva (2007), mentioned in the theoretical framework. This approach derives from the professional competences model proposed by Cheethan and Chivers (1998), which considers the work context and the environment as determinants for the activation of professional competences. The second phase of the analysis was where the available material was explored. The construction of the coding operations was carried out, considering the clippings of the texts in record units resulting from the transcription of the interviews. Then, the various themes established in the interview script were analyzed through the definition of final, intermediate and initial categories. These categories constituted the analytical axis that systematized the data analysis. The keywords that emerged from the content analyzed were grouped into the final categories. The articulation of categories enabled a consistent analysis of the qualitative data obtained in the research. Finally, in the third phase, the data was interpreted based on the thematic categories established in the previous phase. The relevant aspects highlighted by the analysis were highlighted.

\section{Presentation and analysis of results}

In this present section, the results obtained will be presented in harmony with the thematic blocks that constituted the interview script.

The first one involved the characterization of the respondent's profile. In this sense, the results revealed that all managers interviewed occupy the position of Production Supervisor, working at a tactical-operational level. These managers have a very important role in the dialogue with the upper layers of management and in the operationalization of Valvmed's strategic guidelines. Five of the interviewees are female and five are male. Respondents are born in the 1970s and 1980s. Of all, only one respondent is single. Six of them have children. 
Training in the field of engineering predominates. Most respondents (7) have specialization courses. Among them, three attended a specialization course in Production Engineering. One of the interviewees has a master's degree in Production Engineering. Regarding the length of experience in the company, the average is 10.5 years. The interviewee with the least time has been with the company for 3.4 years. Four respondents have more than 10 years of experience at Valvmed, and two of them have been with the company for over 22 years. The data also reveal that production managers establish a lasting relationship with the company. Another relevant aspect is the length of experience in the position. Four respondents have been in the position for less than five years. Five respondents have been in the job for five to ten years. One of the interviewees has been in the position for 18 years. This stability is essential to demonstrate the involvement of managers and, in relation to the work teams, it signals that Valvmed is making efforts to keep its.

The second thematic block refers to the definition of the concept of professional competence. This is a relevant point insofar as different approaches and understandings related to the notion of competence predominate. The identification of the subjects' perception is necessary, because as clarified by authors such as Cheethan \& Chivers $(1996 ; 1998 ; 2000)$, Paiva (2007) and Paiva and Melo (2008), it can determine the professional's view and conduct in the context of work. 


\section{Table 1}

Categorization of terms related to the definition of the "professional competence" concept

\begin{tabular}{|c|c|c|c|c|}
\hline $\begin{array}{c}\text { Final } \\
\text { Category }\end{array}$ & $\begin{array}{l}\text { Intermediate } \\
\text { Category }\end{array}$ & $\begin{array}{c}\text { Initial } \\
\text { Category }\end{array}$ & Total & $\%$ \\
\hline \multirow{10}{*}{$\begin{array}{r}\text { Professional } \\
\text { Competence } \\
(30)=100 \%\end{array}$} & \multirow{3}{*}{$\begin{array}{l}\text { Elements of } \\
\text { Competence } \\
(10)=33 \%\end{array}$} & $\begin{array}{l}\text { Knowledges } \\
\text { knowledges (2), } \\
\text { technical knowledge (1), } \\
\text { human knowledge (1) }\end{array}$ & 4 & $40 \%$ \\
\hline & & $\begin{array}{l}\text { Abilities } \\
\text { abilities (2), execute (1) }\end{array}$ & 3 & $30 \%$ \\
\hline & & $\begin{array}{l}\text { Attitudes } \\
\text { attitudes (1), willingness to act (1), } \\
\text { not limiting to instructions (1) }\end{array}$ & 3 & $30 \%$ \\
\hline & & & & $100 \%$ \\
\hline & \multirow{2}{*}{$\begin{array}{c}\text { Sources of } \\
\text { Acquisition } \\
(9)=30 \%\end{array}$} & $\begin{array}{l}\text { Experience } \\
\text { experience (4), learning (1), } \\
\text { practice (1) }\end{array}$ & 6 & $67 \%$ \\
\hline & & $\begin{array}{l}\text { Individual Aspects } \\
\text { innate (1), personality (1), } \\
\text { characteristics of the person (1) }\end{array}$ & 3 & $33 \%$ \\
\hline & & & & $100 \%$ \\
\hline & $\begin{array}{l}\text { Technical } \\
\text { Dimension } \\
(5)=17 \%\end{array}$ & $\begin{array}{l}\text { Result } \\
\text { result (3), performance (1), technical } \\
\text { competence (1) }\end{array}$ & 5 & $45 \%$ \\
\hline & $\begin{array}{c}\text { Social } \\
\text { Dimension } \\
(6)=20 \%\end{array}$ & $\begin{array}{l}\text { Behavioral Aspects } \\
\text { behavioral competence (1), } \\
\text { deal with people (1), leadership (1), } \\
\text { motivate workers (1), } \\
\text { interpersonal relationship (1), } \\
\text { people management (1) }\end{array}$ & 6 & $55 \%$ \\
\hline & & & & $100 \%$ \\
\hline
\end{tabular}

Source: Content analysis carried out based on research data.

Regarding the concept of professional competence, the data shown in Table 1 show the emergence of seven initial categories, four intermediate categories and a final category. Among the initial categories, "experience" (6 terms), "behavioral aspects" (6 terms) and "result" (5 
terms) stood out. Among the intermediate categories, "elements of competence" (10 terms) and "sources of acquisition" (9 terms) stood out. Considering the number of terms in each category, in general, one can verify the prominence of the following categories: knowledge and elements of competence. This finding indicates that, according to the interviewees, the concept of professional competence is based on technical and behavioral knowledge. The following speech fragments are illuminating: "For me, professional competence (involves) technical knowledge and also human knowledge: treating people in a way that they (achieve) the result that the company wants." (E3); "Competence for me is divided into two lines: the technical competence that (the professional) needs to perform a certain activity and behavioral competence, which means how to treat people." (E6). It could be noted that experience has been considered the main way to acquire competences in the context of the analyzed company.

Several authors (Barbosa, 2003, 2007, Fleury \& Fleury, 2001, Le Boterf, 2003, Montezano et al, 2019, Paiva, 2007, Silva et al, 2017, Zarifian, 2001) admit the diversity of definitions related to the concept of competence professional. In Valvmed's case, respondents highlighted the technical and behavioral dimensions. The first one reflects the pragmatism materialized by a management logic oriented towards results and performance. The technical knowledge used in the execution of tasks is crucial in this dimension, and they assume an operative character based on strict procedures. It is a dimension sufficiently described by Le Boterf (2003) when referring to the professional required by organizations in the changing context of the productive sphere. The second dimension is the behavioral dimension, and it signals that the established relationships are essential for the sector's functional dynamics, as well as for the exercise of the managerial function. The relevance of this dimension was considered by authors such as Mintzberg (2010) and Bitencourt (2005).

As for the third thematic block, it covers the analysis of the competences required of production managers, according to the model by Paiva (2007). In the Metacompetences category, the competences with the highest averages are: communication (average 3.9), conflict management (average 3.7) and functional assessment (average 3.6).

The first two competences refer to the social dimension of work, while the third concerns the technical dimension and performance verification. Regarding the Knowledge/Cognitive category, the competences with the highest averages are: knowledge application (3.8 average), customer knowledge (3.7 average), and procedural knowledge (3.7 average). In relation to the Functional category, the competences with the highest averages are: planning and organization (average 3.9), quality at work (average 3.8) and analytical capacity 
(average 3.7). As shown in Table 11, the competence "motor coordination and manual dexterity" had the lowest measure (2.8). The managerial nature of the work carried out by the research participants must be taken into account. In the Personal / Behavioral category, the competences with the highest averages are: personal mastery (average 3.7), results orientation and tasks (average 3.7). The competence "empathy" obtained the lowest measure (3.2). Nevertheless, it should be noted that, in general, all competences in this category have been well evaluated. In relation to the Values/Ethics category, the competences with the highest averages are: ethical judgment (3.7 average), customer orientation (3.7 average). The competency "sensitivity to the needs and values of others" obtained the lowest measure (3.3). However, it should be noted that, in general, all competences in this category were well scored. Finally, in the Political category, the competences with the highest averages are: maintaining professionalism (average 3.6) and power in the context of the company (average 3.27). The following competences had the lowest averages "power in social relations" (average 2.8) and "perception about particular political games" (average 2.8). It can be observed that competences linked to the different categories proposed in Paiva's (2007) model were mentioned. That alignment signals adherence of the analytical model to the context of the company in which the analysis was carried out. Furthermore, the means with high values confirm this relationship. It is an observation based on the perspective of the managers themselves. It was considered that these organizational actors have in-depth knowledge of the company's environment, seeing, with knowledge of the facts, the limits and possibilities of the production area.

Table 2 shows the categories related to the competences required and that emerged from the Content Analysis carried out. 
Table 2

Categorization of terms related to required competences

\begin{tabular}{|c|c|c|c|c|}
\hline $\begin{array}{c}\text { Final } \\
\text { Category }\end{array}$ & $\begin{array}{c}\text { Intermediate } \\
\text { Categories }\end{array}$ & $\begin{array}{c}\text { Initial } \\
\text { Categories }\end{array}$ & Total & $\%$ \\
\hline \multirow{7}{*}{$\begin{array}{l}\text { Competence } \\
(32)=100 \%\end{array}$} & \multirow[t]{2}{*}{$\begin{array}{c}\text { Profile } \\
(14)=44 \%\end{array}$} & $\begin{array}{l}\text { Attributes of the } \\
\text { Individual } \\
\text { motivation (1), listening (1), } \\
\text { responsibility (1), } \\
\text { critical analysis (1), } \\
\text { self-knowledge (1), } \\
\text { seek improvement (1), } \\
\text { seek continuous } \\
\text { improvement (1), } \\
\text { analytical capacity (1), } \\
\text { emotional intelligence (1), } \\
\text { following rules (1), } \\
\text { delegation (1) }\end{array}$ & 11 & $79 \%$ \\
\hline & & $\begin{array}{l}\text { Qualification } \\
\text { fluency in English (1), } \\
\text { academic background (1), } \\
\text { technical competence (1) }\end{array}$ & 3 & $21 \%$ \\
\hline & & & & $100 \%$ \\
\hline & \multirow{4}{*}{$\begin{array}{c}\text { Management } \\
(18)=56 \%\end{array}$} & $\begin{array}{l}\text { Leadership } \\
\text { leadership (3), } \\
\text { correct decision making (1), } \\
\text { systemic vision (1) }\end{array}$ & 5 & $28 \%$ \\
\hline & & $\begin{array}{l}\text { Communication } \\
\text { communication (2) }\end{array}$ & 2 & $11 \%$ \\
\hline & & $\begin{array}{l}\text { People Management } \\
\text { develop people (1), } \\
\text { manage people (3), } \\
\text { deal with people (2), } \\
\text { interpersonal relationships } \\
(2)\end{array}$ & 8 & $44 \%$ \\
\hline & & $\begin{array}{l}\text { Processes } \\
\text { tools }(1), \text { time management } \\
(1), \text { control processes }(1)\end{array}$ & 3 & $17 \%$ \\
\hline
\end{tabular}

Source: Content Analysis carried out bases on research data. 
Table 2 shows that from the terms that were identified in the Content Analysis, six initial categories, two intermediate categories and one final category emerged. Among the initial categories, "attributes of the individual" (11 terms) and "people management" ( 8 terms) stood out. Among the intermediate categories, "management" (18 terms) stood out. Taking into account the number of terms in each category, in general, it can be seen that the following categories stand out: management and people management. The individual's attributes were identified as decisive elements that influence the managerial function. Yet again, the relational content of the activity of production managers emerged in the interviewees' speech: "One thing I think we need to have is a skill in interpersonal relationships, both with shop floor operators, as with peers and between departments." (E2); "[...] dealing with people, knowing how to listen to them, honestly absorbing as much as that person has to give. But from my point of view it's how to deal with people.” (E6); “[...] responsibility, interpersonal skills. We receive a lot of information and we have to be the filter for our collaborators. We have to lead." (E7). Fleury and Fleury (2001) considered that a manager's competences are related to several actions. In the view of Valvmed managers, these competencies fall into broader categories, such as: leadership, communication, people and process management. Fleury and Fleury (2001), Dutra (2004) and Ruas (2010), among others, point out the importance of the manager establishing relationships as a way to achieve results through people. Given the tendency of organizations to assign people management roles to line managers, as explained by Ulrich et al (2011), it is essential to develop behavioral competences that allow them to establish a dialogue with their subordinates, peers and superiors (Mintzberg, 2010, De Toni et al, 2012). The relational content proved to be essential to the managerial activity.

In the fourth thematic block, the degree of importance and the level of mastery of competences will be seen. Table 3 shows that, in general, the categories achieved high averages. The Metacompetence category stood out for the degree of importance (3.53) and the Values and Ethics category for the level of mastery (3.59). The Political category had the lowest averages, in relation to the degree of importance (3.08) and level of domain (2.83). The results indicate that respondents have a lower perception of domain when it comes to political competence. The fact that production managers act in the tactical-operational position may have influenced their view. Thus, it should be considered that the focus of the activity involves the execution of procedures, fundraising and application of resources, to the detriment of a more active participation in the political sphere and in the determination of macro organizational strategies. Although they can perform activities inherent to the political dimension, this seems 
to be overshadowed by the almost immediate need to generate concrete results in terms of production.

\section{Table 3}

Averages per category - level of importance and level of domain

\begin{tabular}{l|c|c}
\hline \multicolumn{1}{c|}{ Category } & Level of importance & Level of domain \\
\hline Metacompetence & 3.53 & 3.54 \\
Values / Ethics & 3.50 & 3.59 \\
Functional & 3.49 & 3.31 \\
Knowledge / Cognitive & 3.46 & 3.19 \\
Personal /Behavioral & 3.45 & 3.54 \\
Politics & 3.08 & 2.83
\end{tabular}

Source: Created by the authors based on research data.

The fifth thematic block deals with initiatives related to competence development in the context of Valvmed. From Content Analysis, five initial categories, two intermediate categories and one final category emerged. Among the initial categories, the one named "empowerment" (17 terms) stood out. Among the intermediate categories, "organizational actions" (27 terms) stood out. The results obtained show that the company plays a leading role in the process of developing managerial competences, being the main responsible for training actions. The speech fragments, highlighted below, are clarifying: "The Company invests a lot in multifunctional training [...] job rotation [...]. We leave the comfort zone (the company, which requires a new attitude." (E1) "I've already done external training, in another state, and some internal ones. I think they were very good.” (E2). It was observed that the offer of internal and external training has been frequent, and this is an essential way to acquire knowledge. Thus, "training" and "openness to learning" were the words most cited by respondents. "Job rotation," as an important aspect of the competence development process, it was also mentioned by respondents. It should be considered that this practice displaces managers from a given context, stimulating learning and professional maturity. The following speech fragments confirm this: "I've already experimented two job rotations, I had contact with different situations, and I was able to experience the entire production process. I started as an intern, then I was hired as a technician, then I became a supervisor and continued my way." (E1). The incentives for training were mentioned: "I have already received the benefit of a scholarship to study at the Institute of Technological Education (IETEC). I received scholarship support to study English. I've 
already had opportunities to take courses in another city, like São Paulo." (E10). Fleury and Fleury (2001) and Dutra (2004) are authors who highlight the relevance of training actions by companies. They consider that the practices related to the development of competences vary depending on the sector in which they operate, the business model and the organizational culture itself (Barbosa, 2007; Lima, Giroletti \& Barbosa, 2012, Lima, 2013). For the development of competences, organizations and their professionals employ formal and informal means based on learning processes (Le Boterf, 2003, Zarifian, 2001). The terms "serving a diverse audience", "establishing communication" and "people management" were the most cited in the interviewees' statements when asked about the possible challenges related to the development of competences. The analysis resulted in three initial categories, two intermediate categories and one final category. Among the initial categories, "individual attributes" (8 terms) stood out. Among the intermediate categories, the "social dimension" (13 terms) was highlighted. Taking into account the number of terms in each category, in general, it can be seen that the challenges related to the development of competences involve individual attributes and are related to the social dimension of work.

Table 4 presents a synthesis of the research results, indicating that the configuration of the competence approach at Valvmed still takes on traditional contours. 


\section{Table 4}

Summary of results

\begin{tabular}{|c|c|}
\hline Items & Results \\
\hline (1) interviewee profile & $\begin{array}{l}\text { Managers in the positions of Production Supervisors, at } \\
\text { the tactical-operational level. They have a decisive role in } \\
\text { the operationalization of strategies and in the dialogue } \\
\text { between the different layers of management. They are } \\
\text { professionals with experience and long-lasting bonds with } \\
\text { the company. }\end{array}$ \\
\hline (2) concept of competence & $\begin{array}{l}\text { From the point of view of the interviewees, professional } \\
\text { competence involves the technical and behavioral } \\
\text { dimensions. The operational knowledge linked to the } \\
\text { achievement of results is essential, while the relationships } \\
\text { established in the managerial function are relevant to the } \\
\text { functional dynamics of the sector and to the exercise of } \\
\text { the managerial function. }\end{array}$ \\
\hline (3) required competence & $\begin{array}{l}\text { The link between the Paiva (2007) model and the } \\
\text { competences required in the company was observed. In } \\
\text { the view of the managers, the competences required are } \\
\text { part of broad categories that, in the analysis, were named: } \\
\text { leadership, communication, people and process } \\
\text { management. The relational content proved to be essential } \\
\text { to the managerial activity. }\end{array}$ \\
\hline $\begin{array}{l}\text { (4) degree of importance and level of } \\
\text { mastery of competences }\end{array}$ & $\begin{array}{l}\text { The results show that, in general, the constituent } \\
\text { categories of Paiva's (2007) model obtained high averages } \\
\text { in relation to the degree of importance and the level of } \\
\text { domain by managers. Respondents have a lower } \\
\text { perception of mastery of political competence }\end{array}$ \\
\hline $\begin{array}{l}\text { (5) Initiatives related to competence } \\
\text { development. }\end{array}$ & $\begin{array}{l}\text { The development of competences involves training and } \\
\text { experience, generated by the company's initiatives: } \\
\text { Training, job rotation, English language courses. The } \\
\text { challenges include attributes of the individual and related } \\
\text { to the social dimension of work. }\end{array}$ \\
\hline
\end{tabular}

Source: Prepared by the authors based on research data.

\section{Final considerations}

The research carried out was based on the following generating question: "In relation to the managers who work in the production area at Valmed, how is the competence approach configured?" The investigative process involved secondary inquiries related to the profile of managers, the concept of professional competence, the required competences, the degree of importance and domain of competences, and initiatives focused on the development of managerial competences.

It could be observed that, in the analyzed company, the competence approach is configured through an integrated set of aspects that range from the profile of the managers to the practices effectively applied in the context of the company with a focus on the development of competences. 
It could be verified that the researched ones play a relevant role in the production area, acting at the tactical-operational level. They have experience and develop lasting bonds. This is a strategy adopted by Valvmed to stabilize the workforce and encourage the involvement of managers.

In the view of production managers, the concept of professional competence includes the technical and behavioral dimensions. This perception deserves attention because it is an area whose work dynamics are determined by strict procedures, standards and metrics. The rational character of the activity is materialized in the definition of goals and objectives, according to the unfolding of the corporate guidelines. Thus, in addition to the technical content, the research showed that the managerial role requires relational and behavioral competences, as the Production Supervisor interacts with several professionals and seeks results through people.

Regarding the required competences, the perception of the managers signaled the applicability of the Paiva (2007) model and its relevance for the analysis of the studied context. According to the managers' point of view, the required competencies relate to broad categories, which are: leadership, communication, people and process management. Generally speaking, they are in tune with the model. It must be emphasized that the research was not aimed at seeking new analytical categories or even suggesting changes in the aforementioned model. It was used only as a theoretical lens for analyzing the object of study.

The results indicate that, in general, the constituent categories of Paiva's (2007) model had high averages in relation to the degree of importance and level of domain by the managers. Respondents indicated lesser perception of domain about political competence.

Regarding the development of competences, the research showed the relevance of several aspects. Initiatives related to the training of managers and the expansion of work experience were identified. Actions such as training and job rotation were considered positive, in addition to stimuli for training, such as subsidies for taking language courses. Skills development is a complex process that entails different challenges. The research revealed that, in the context of Valvmed, attributes of the individual and aspects inherent to the social dimension of work generate challenges for managers. Thus, the relevance of initiatives aimed at improving the management body through the acquisition of knowledge, skills and attitudes capable of sustaining managerial competences was noted.

Ultimately, the research revealed an oxymoron. Although Valvmed is a multinational company that manufactures high-tech medical devices and operates in a dynamic sector, in the 
perception of production area managers, the competency approach is still configured in a traditional way. In this sense, the innovative character of the company is related to production processes and products and, not necessarily, to the people management model adopted or to practices aimed at building managerial competences. The research revealed another interesting aspect about the production environment. Although the area is traditionally characterized by its mechanistic and technical nature, it was possible to identify the demand for relational and behavioral competences that point to the relevance of the social content of the work. The research was able to contribute to managers who work in this field by stimulating reflections on the inherent complexity of production management and the need for the company to make efforts to improve managerial competences that enhance human interaction.

As a limitation of the study, the non-inclusion of managers from other areas of the company in the research corpus is mentioned. It was understood that their presence could broaden the analysis, pointing out new elements. It is suggested that future research be carried out with a focus on managerial competences, comprising: (1) a study of a comparative nature between the corporation's units located in other countries. (2) a longitudinal study on possible changes in the process of developing managerial competences and the insertion of new analytical categories in the Paiva (2007) model.

\section{References}

Antonello, C. S. (2011). Contextos do saber. A aprendizagem informal. In: Antonello, C. S. (org). Aprendizagem organizacional no Brasil. Porto Alegre: Bookman. p. 139-159.

Avelino, G. I. B., Nunes, S. C., \& Sarsur, A. M. (2016). Modelo de gestão por competências: a aderência dos gestores para o alcance do desempenho organizacional superior. Economia e Gestão, 16 (44), 24-50. https://doi.org/10.5752/P.19846606.2016v16n44p24

Barbosa, A. C. Q. (2007 out-dez). Utopia com os pés no chão? A gestão de competências pela perspectiva social: experiências setoriais no Brasil. Salvador, Revista Organização \& Sociedade, 14(43), 57-70.

Barbosa. A. C. Q. (2003). Um Mosaico da Gestão de Competências em Empresas Brasileiras. RAUSP. Revista de Administração. São Paulo, 38 (4), p. 285-297.

Bardin, L. (2011). Análise de conteúdo. São Paulo: Edições 70. W. G. (1996). A formação do líder. São Paulo: Atlas.

Bitencourt, C. C. (2005). A gestão de competências como alternativa de formação e desenvolvimento nas organizações: uma reflexão crítica baseada na percepção de um grupo de gestores. In. Ruas, R.; Antoniello, C. S.; Boff, L. H. (org.). Os novos 
horizontes da gestão: aprendizagem organizacional e competências. Porto Alegre: Bookman, p.132-149.

Boyatzis, R. E. (1982). The competent Manager: a model for effective performance. New York: John Wiley.

Carbone, P. P., Brandão, H. P., Leite, J. B. D., \& Vilhena, R. M. de P. (2011). Gestão por competência se gestão do conhecimento. 3. ed. Rio de Janeiro: FGV.

Caetano, A. G. L. S.; Meireles, G. S. C.; Oliveira, J. F. G. \& Leão e Souza, G.W. (1999). Informações de chão de fábrica num ambiente de manufatura integrada. Congresso $e$ Exposição Internacionais da Tecnologia da Mobilidade (SAE Brasil 99), SAE Technical Paper Series.

Ceribeli, H. B., Maciel, G. N., \& Guilarducci, C. A. (2017). Gestão por competências no Brasil: um estudo multicascos. Reuna, 22 (4), 20-39. http://dx.doi.org/10.21714/2179$8834 / 2017 \mathrm{v} 22 \mathrm{n} 4 \mathrm{p} 20-39$

Cheetan, G., \& Chivers, G. (2005). Professions, competence and informal learning. Cheltenham, UK: Edward Elgar.

Cheetan, G., \& Chivers, G. (2000). A new look at competence professional practice. Journal of European Industrial Training. 24(7), 374-383. https://doi.org/10.1108/03090590010349827

Cheetan, G., \& Chivers, G. (1998). The reflective (and competences) practioner: A moldel of professional competence which seeks to harmonize the reflective practioner and competence-based approaches. Journal of European Industrial Training, 2(7). 267276. https://doi.org/10.1108/03090599810230678

Cheetan, G., \& Chivers, G. (1996). Towards a holistic model of professional competence. Jornal of European Industrial Training. 20(5). 20-30. https://doi.org/10.1108/03090599610119692

Corrêa, H. L., Gianesi, I.G.N., \& Caon, M. (1997). Planejamento, programação e controle de produção: MRPII/ERP. Editora Atlas, São Paulo.

Chouhan, V. S., \& Srivastava, S. (2014). Understanding Competencies and Competency Modeling - A Literature Survey. Journal of Business and Management. 16 (1), 14-22. https://doi.org/10.9790/487X-16111422

De Toni, D., Mattia, A, Larentis, F, Silva, M. G. da., \& Milan, G. S. (2012 set-dez.). O perfil dos gestores: um estudo exploratório dos modelos mentais e das competências. Revista Eletrônica de Gestão Empresarial - PROPAD/UFPE, Pernambuco, 3 (10), 537-566. https://doi.org/10.51359/1679-1827.2012.21720

Dutra, J. S. (2004). Competências: conceitos e instrumentos para gestão de pessoas na empresa moderna. São Paulo: Gente 
Fleury, M.T.L., \& Fleury, A. (2001). Estratégias empresariais e formação de competências: um quebra-cabeça caleidoscópico da indústria brasileira. São Paulo: Atlas.

Godoy, A. S., \& D'Amelio, M. (2012). Competências gerenciais desenvolvidas por profissionais de diferentes formações. Organizações \& Sociedade, 19(63), 621639. https://dx.doi.org/10.1590/S1984-92302012000400004

Godoy, A. S., Antonello, C. S., Bido, D. S., \& Silva, D. (2009 jul-set.). O desenvolvimento das competências de alunos formandos do curso de Administração: um estudo de modelagem de equações estruturais. Revista de Administração - RAUSP, São Paulo, 44(3), 265-278.

Harari, Y. (2018). 21 lições para o século 21. São Paulo: Companhia das Letras.

Kanet, J. J., \& Sridharan, S. V. (1998 sept.). Dynamic manufacturing planning and control. Industry Week, 21.

Le Boterf, G. (2003). Desenvolvendo a competência dos profissionais. Porto Alegre: Artmed.

Leite, I. C. B, V. (2011). O aprendizado da função gerencial por meio da experiência. In: Antonello, C. S.; Godoy, A. S. (Org.). Aprendizagem organizacional no Brasil. Porto Alegre: Bookman, p.201-224.

Lima, R. J. C., Barbosa, A. C. Q., \& Cintra, L. P. (2015). Competências e cultura organizacional. In. Barbosa, A. C. Q. (Org) Recursos Humanos: Contemporaneidade, Limites e Possibilidades Teóricas e Aplicadas. Curitiba: CRV.

Lima, R. J. C., Barbosa, A. C. Q., Baeta, A. M. C., \& Giroletti, D. A. (2012). Valores e Construção de Competências Coletivas no Complexo Têxtil: Reflexões e Evidências. Revista Gestão \& Tecnologia, 12(1), 102-125. https://doi.org/10.20397/2177-6652/2012.v12i1.399

Mintzberg, H. (2010). Managing. Desvendando o dia a dia da gestão. Porto Alegre: Bookman.

Montezano, L., Medeiros, B. N., Isidro-Filho, A., \& Petry, I. S. (2019 mai-ago). Panorama da Produção Científica da Gestão por Competências na Administração Pública Brasileira (2008 a 2018). Revista Contabilidade, Gestão e Governança. Brasília, 22 (2), 280298. http://dx.doi.org/10.21714/1984-3925_2019v22n2a8

Morgan, G. (1996). Imagens da organização. São Paulo: Atlas.

Munck, L., Souza, R. B. Castro, A. L. \& Zagui, C. (2011). Modelos de gestão de competências versus processo de validação. Um ponto cego?. Revista de Administração, 46,(2), 107-121. http://10.5700/rausp1001

Paiva, K., C., M., \& Melo, M. C. O. L. (2008). Competências, gestão de competências e profissões: perspectivas de pesquisas. Revista de Administração Contemporânea, 12(2), 339-368. https://doi.org/10.1590/S1415-65552008000200004 
Paiva, K. C. M. (2007). Gestão de competências e a profissão docente: um estudo em universidades no Estado de Minas Gerais. Tese (Doutorado em Administração). Universidade Federal de Minas Gerais, Belo Horizonte, Brasil.

Pereira, S. A. (2018). Complexo Econômico Industrial da Saúde: os reflexos jurídicos dos estímulos ao desenvolvimento tecnológico previstos na Lei $\mathrm{n}^{\circ} 13.243 / 2016$. Cadernos Ibero-Americanos de Direito Sanitário., Brasília, 7(1):96-110, jan./mar, 2018. http://dx.doi.org/10.17566/ciads.v7i1.436

Pereira, J. A., Carvalho, J. S., \& Santos, R. H. dos. (2015, março). O gestor de produção na indústria de confecções: um estudo em uma empresa de médio porte da cidade de Maringá - PR. Revista Produto \& Produção, 16, p. 66-80. https://doi.org/10.22456/1983-8026.42177

Pires, Ana Luiza R., Bierhalz, Andréa C. K., \& Moraes, Ângela M. (2015). Biomateriais: Tipos, Aplicações e Mercado. Química Nova. Sociedade Brasileira de Química. v. 38, n.7, p. 957-971. http://dx.doi.org/10.5935/0100-4042.20150094

Prahalad, C. K., \& Hamel, G. (1990 May-Jun.). The core competence of the corporation. Harvard Business Review, 68(3), 79-91. http://10.1007/3-540-30763-X_14

Quinn, R. E., Faerman, S. R., Thompson, M. P., \& McGrath, M. (2003). Competências gerenciais: princípios e aplicações. Rio de Janeiro: Elsevier.

Richardson, R. J. (1999). Pesquisa social: métodos e técnicas. São Paulo: Atlas.

Ruas. R. L. (2010). Desenvolvimento de competências gerenciais e contribuição da aprendizagem organizacional. In: Fleury, M. T. L.; Oliveira Jr, M. M. (org.). Gestão estratégica do conhecimento: integrando aprendizagem, conhecimento e competências. São Paulo: Editora Atlas, 2010. p. 242-269.

Sant'Anna, A. S., Moraes, L. F. R., \& Kilimnik, Z. M. (2005). Competências individuais, modernidade organizacional e satisfação no trabalho: um estudo de diagnóstico comparativo. RAE electron., 4(1), 1-23. https://doi.org/10.1590/S167656482005000100001

Schwab, K. (2016). A Quarta Revolução Industrial. São Paulo: Edipro.

Silva, A. H., \& Fossá, M. I. T. (2015 jan-jun). Análise de conteúdo: exemplo de aplicação da técnica para análise de dados qualitativos. Qualit@s Revista Eletrônica, 16 (1). http://dx.doi.org/10.18391/qualitas.v16i1

Silva, P. A., Cavalcante, S. M. A., Macedo, A. C. M., Ribeiro Silva, M. R., \& Silva Araújo, P. (2017 novembro). Gestão por Competência: um estudo bibliométrico das publicações na área de Administração entre 2006 e 2016. XX SEMEAD - Seminários em Administração - São Paulo: USP. 2017.

Slack, N., Chambers, S, \& Johnston, R. (2009). Administração da Produção e Opercações. São Paulo: Atlas. 
Spencer, L., \& Spencer, S. (1993). Competence at work: models for superior performance. New York: John Wiley \& Sons.

Souza, F. B., \& Pires, S. R.I (1999 - ago.). The influence of task interruption on individual decision making: na information overload perspective. Decision Sciences, 30 (2),111126. https://doi.org/10.1111/j.1540-5915.1999.tb01613.x

Ulrich, D., Allen, J.,Brockbank, W.,Younger, J., \& Nyman, M. (2011). A Transformação do RH - Construindo os recursos humanos de fora para dentro. (cap. 4, pp. 113 -136). Porto Alegre: Bookman.

Yin, R. K. (2010). Estudo de caso: planejamento e métodos. (4. ed.), Porto Alegre: Bookman. Zarifian, P. (2001). Objetivo competência: por uma nova lógica. São Paulo, Atlas. 